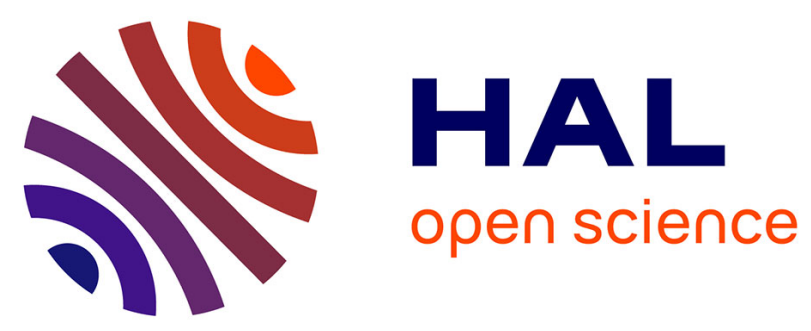

\title{
Maps, actors \& local policies around earth buildings in Auvergne Rhône-Alpes
}

\author{
Grégoire Paccoud, Mathilde Chamodot Chamodot, L Génis, F Gutiérrez,
} Emmanuel Mille, Bakonirina Rakotomamonjy, J Avons-Bariot, Dora Studer

\section{- To cite this version:}

Grégoire Paccoud, Mathilde Chamodot Chamodot, L Génis, F Gutiérrez, Emmanuel Mille, et al.. Maps, actors \& local policies around earth buildings in Auvergne Rhône-Alpes. International Conference on Vernacular Earthen Architecture, Conservation and Sustainability (SOStierra2017), Sep 2017, Valence, Spain. hal-01726667

\section{HAL Id: hal-01726667 https://hal.science/hal-01726667}

Submitted on 8 Mar 2018

HAL is a multi-disciplinary open access archive for the deposit and dissemination of scientific research documents, whether they are published or not. The documents may come from teaching and research institutions in France or abroad, or from public or private research centers.
L'archive ouverte pluridisciplinaire HAL, est destinée au dépôt et à la diffusion de documents scientifiques de niveau recherche, publiés ou non, émanant des établissements d'enseignement et de recherche français ou étrangers, des laboratoires publics ou privés. 


\title{
Maps, actors \& local policies around earth buildings in Auvergne Rhône-Alpes
}

\author{
G. Paccoud, M. Chamodot, L. Génis, F. Gutiérrez, E. Mille \& B. Rakotomamonjy \\ AE\&CC CRAterre-ENSAG, Université Grenoble Alpes, Grenoble, France
}

\section{J. Avons-Bariot \& D. Studer \\ Osmia Architecture, Grenoble, France}

\begin{abstract}
The paper presents and analyzes the activities undertaken during the first part of an ongoing research project, which aimed at a better knowledge of the rammed earth architectural heritage in in Auvergne-Rhône-Alpes region and at describing the promotion policies of this heritage. We first describe the results of localizing, identifying and mapping remarkable rammed earth sites and the local initiatives in the region. Then, we explain how this research engaged a coconstruction process concerning the tools and mechanism to develop around rammed earth historic and vernacular building promotion and inclusion in local policies frameworks.
\end{abstract}

In Auvergne-Rhône-Alpes Region, France, up to $80 \%$ of the old buildings are built in rammed earth in some villages, representing a noteworthy rammed earth heritage. They represent a wide variety of buildings, including country or city houses, mansions, agricultural buildings, public buildings, schools, churches or industrial buildings. Since the end of the seventies, various initiatives were developed to start anew earth building and promote this heritage. They also contributed to understand its architecture, its diversity, its distribution and the specific know-how linked to its retrofitting.

In some of these actions, the old rammed earth constructions of the region were grasped as a development tool for local dynamics. It is therefore part of a global movement that view heritage as a support for territorial project (Magnaghi, 2003, Micoud, 2007). We considered it relevant to develop a research on these dynamics and examine them through the following questions:

- How are historic and vernacular rammed earth constructions distributed and identified on the territory? ${ }^{i}$ How are they used in the development of local dynamics?

- What are the actions implemented locally to use them as a development tool? How could these initiatives be linked together? Could they take part in the development of consistent public policies in terms of conservation and promotion of the built heritage, as well as of town and country planning?

This research project named "Promotion of the rammed earth heritage in Auvergne-Rhône-Alpes Region" is part of the Rhône-Alpes Development Contract Isère, Porte des Alpes, funded by RhôneAlpes Region. It follows on from 15 years of rammed earth promotion projects lead by CRAterre on this territory. It is coordinated by the research unit Architecture, Environnement et Cultures Constructives from Ecole Nationale Supérieure d'Architecture de Grenoble ${ }^{\mathrm{ii}}$, and by CRAterre association.

This research aims at a better knowledge of the rammed earth architectural heritage in AuvergneRhône-Alpes Region. It also aims at describing the promotion policies of this heritage, understanding the values that are linked to it and the organization of the stakeholders that make it a living heritage. The project is about developing work methods and tools that can be used in the policy framework of the local authority or be decision making support for town and country planning.

The project activities were structured around two main objectives: 
- localizing, identifying and mapping remarkable rammed earth sites and the local initiatives in Auvergne-Rhône-Alpes region;

- engaging in exchanges and discussions on the tools and mechanisms used or to develop around its promotion and valorization.

The paper presents and analyzes the activities undertaken during the first part of this ongoing research project that started at the beginning of 2016. We will focus on the results considering the whole Auvergne-Rhône-Alpes region, putting aside the results targeted at the territory of Isère, Porte des Alpes.

\section{LOCALIZING RAMMED EARTH}

The aim of this part of the research was to draw up an overview of the historic rammed earth constructions in Auvergne-Rhône-Alpes, with a focus on the sites subjected to heritage protection.

\section{Existing data}

The first step was an analysis of the existing data. From the 19th century, studies about heritage and vernacular buildings have been implemented to document it: "Dauphiné" and "Lyonnais" of the Corpus d'Architecture Rurale (Raulin, 1977, Royer, 1979) and the national Inventaire Général can include information about construction materials such as rammed earth (Guibaud, 2005). Local building analysis were also designed to have an effect on these constructions (EDF-PACT, 1985). Concurrently with these institutional processes, research focused on earthen architecture has been initiated: mapping, made between 1981 and 1991 (Scarato, 1984), more localized census during research projects (Bertin and Clémençon, 1983) or heritage promotion projects (Joffroy et al., 1991). Various researches are underway with new aims: participatory inventories for urban rammed earth (Mille, 2016) or linked with town and country planning policies (Studer, 2016).

\section{Method}

So as to draw up this overview, three datasets were set-up: constructions and sites listed or classified as "Monument Historique" and where rammed earth can be found (1), protected areas that can include rammed earth (2), municipalities where rammed earth constructions can be found (3). The survey was made with two tools: a spreadsheet (list of Historical Monuments and heritage protection areas) and a geographic information system (GIS) for the database of municipalities where rammed earth can be found. An iterative process was set-up. Data collected on the ground, online or from partners (i.e. Service Régional de l'Inventaire, Unités départementales

d'architectures et du patrimoine, CRAterre team, Lionel Bichonnet) was summarized into a map. Successive updates led to the current version of the map. Intermediate versions, online or on paper, were used as mediation supports all along the project activities.

The research for listed or classified sites called upon online heritage databases (e.g. Base Mérimée), webpages dedicated to tourism in each territory and documentation from various projects already undertaken (e.g. Terra Incognita Project).

The research for heritage protection areas was made by crossing the GIS files of the protected zones (data from Atlas des Patrimoines) with the areas where rammed earth is present as surveyed by CRAterre-ENSAG laboratory (Leylavergne \& Beziane, 2012) and with the data of the protected zone's diagnosis reports available on line. The research for rammed earth presence called upon already existing mapping (e.g. (Scarato, 1984)) and the knowledge of the members of CRAterreENSAG laboratory and other partners. It was checked and completed by a systematic rammed earth visibility check in online photographic data (Google Street View) as well as through visits on site. 


\section{Results}

All these information are rendered as a static map (Fig. 1) and as datasets (csv). Historical Monuments are also geolocalized on the web (cartoterra.net). This online application allows in the "Terres à Pisé" group to update a georeferenced dataset about the remarkable historic and vernacular rammed earth constructions in the Region.

Those three datasets confirm the significance of historic rammed earth constructions in the region, as much by the geographical area concerned as by the variety of the buildings and sites identified. More than a quarter of all municipalities in Auvergne-Rhône-Alpes region have been identified as including rammed earth. Rammed earth constructions can represent more than $40 \%$ of the overall constructions in some municipalities. However, the precision of the collected data doesn't allow yet to establish reliable projections on the number of rammed earth buildings in the region.

Part of these buildings are already covered by heritage protection dispositions: 60 sites are listed or classified as "Monument Historique", and only two of them are in the Auvergne part of the region. It can be noted at this stage a preeminence of rammed earth in the former region Rhône-Alpes, which is caused in part by the lack of data for Auvergne area.

\section{Limits}

The whole process generated relatively reliable although not complete datasets. They will require to be updated as the research goes on. Thus, for the identification of the municipalities where rammed earth exists, the limits of the areas where rammed earth is present still needs to be explored. This is especially true for the territories of the former Auvergne region.

The research by keyword in the various heritage databases does not ensure to spot all the monuments and sites concerned as the building technique is not a specific and mandatory field. Furthermore, the building technique doesn't always appear in the description. 


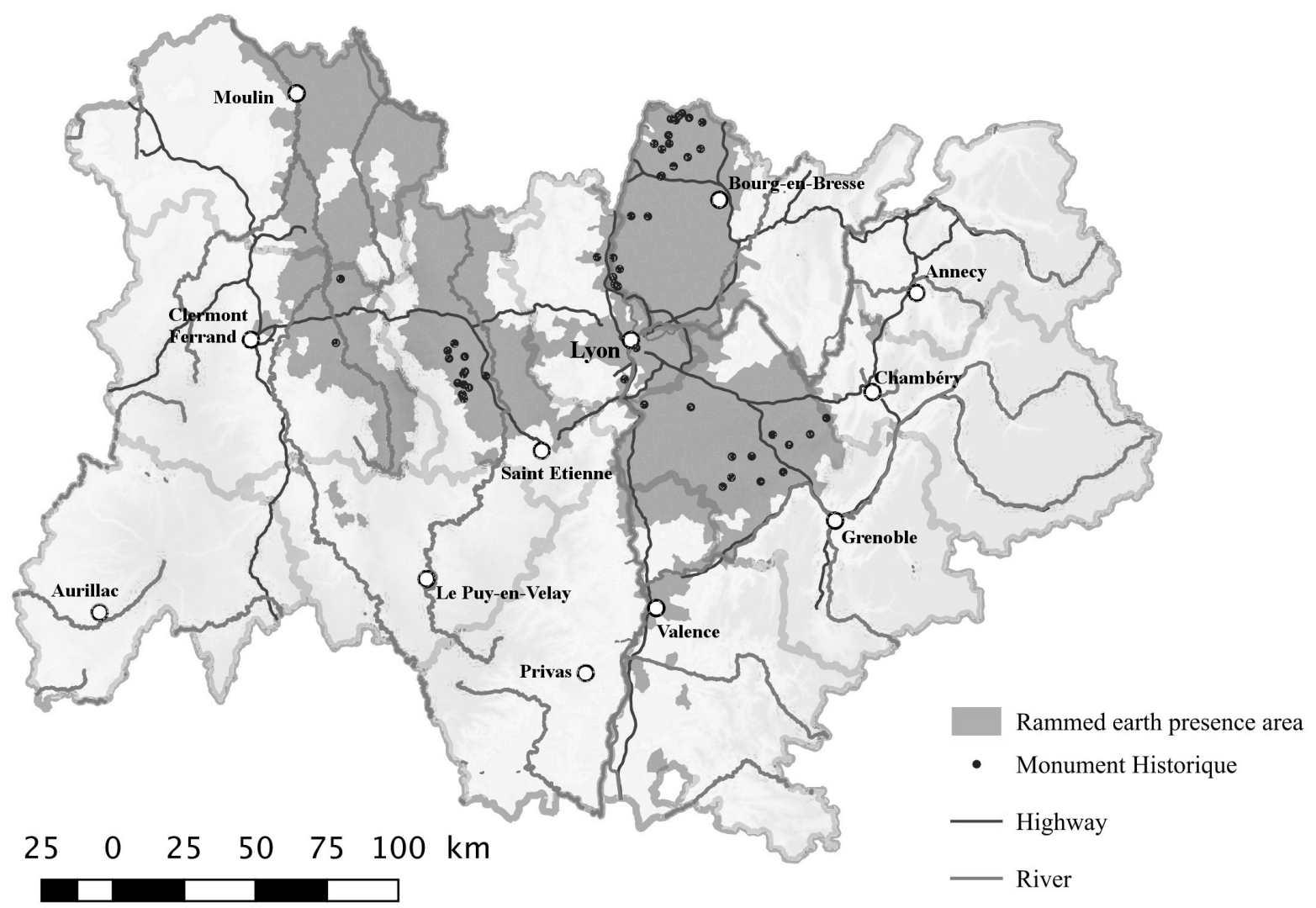

Figure 1: Historic rammed earth in Auvergne-Rhône-Alpes

All inventory data is not necessarily digitized and available online, and the tools used at different scales by the various heritage institutions are not always interoperable.

The wording used in the heritage databases can require checking: some uses of "rammed earth" did not fit with the use of the technique but rather to the use of earth as building material in a wooden structure (wattle and daub). Some monuments identified from the keyword "rammed earth" in Mérimée database were consequently deleted from our file after additional documentation research. Some were also deleted pending the verification of an effective use of rammed earth for their erection.

\section{IDENTIFYING RAMMED EARTH PROMOTION ACTIONS OF THE LAST DECADES}

Since the end of the seventies, various actors of the public sector organized actions to improve knowledge, preservation and retrofitting of vernacular rammed earth buildings. These actions can be very different, according to the targeted public, the medium or the time extent of the action.

The second part of our project aimed at identifying these actions to show their number and diversity.

Drawing up this overview aims at improving the consistency between projects and territorial stakeholders according to their field of activity. It also aims at analyzing these initiative's tendencies and thus to point out potential lacks in the type of actions or in the targeted publics. 


\section{Method}

This projects or initiatives research was undertaken during two weeks. This limited time excludes the possibility to reach a complete result. Choice was made to focus on projects or initiatives engaged by public or nonprofit organizations. This is to mitigate the lack of knowledge of the actions of these organizations towards rammed earth and to avoid favoring private organizations.

Data collection was made through web search and discussions with relevant individuals linked either to the territory or to the research theme. Collected data were gathered in a spreadsheet to ease their sorting.

The following criteria were analyzed: location of the actions, number per Department, timeframe of the actions ( 5 years range), representativeness of the actions' types, targeted public (level 1 : general public of the action, level 2 : publics targeted by the specific action).

\section{Results}

77 initiatives or projects were identified from 1977 to 2016 . The territorial distribution of the initiatives is very unequal in the region: it can be noted that the departments that count the most initiatives on their territory are Isère and Rhône. Departments presenting rammed earth such as Savoie or Drôme count almost no project on the theme. However, it is probable that a bias is caused by the existing network of the research team, making some zones more visible. It is therefore not possible to decide on the correlation between number of actions and significance of the rammed earth buildings in the territory.

Two highlights are noted (Fig. 2): the first is linked to the setup of heritage policies from the eighties, which helped projects about rammed earth constructions to emerge. CRAterre laboratory and other study groups ("groupe Pisé" in Ain département) as well as the local councils for architecture, urbanism and environment (CAUE) were created in these circumstances. The second highlight starts from 2000 and shows an increasing number of actions until today. This interest seems to be part of a growing attention paid to environmental issues, through retrofitting and the use of natural materials for building. The tendency can also be explained by the increased use of web based communication since 2000, when a main data source for the study has been the web. This study shows publications as the main type of actions (Fig. 3). They can be of different kind (book, leaflet, charter, etc.). A very large majority of all actions are targeted to "general public": sensitization actions for rammed earth building owners, pedagogical projects for kids. Many projects also target private sector professionals however very few are meant for public sector professionals.

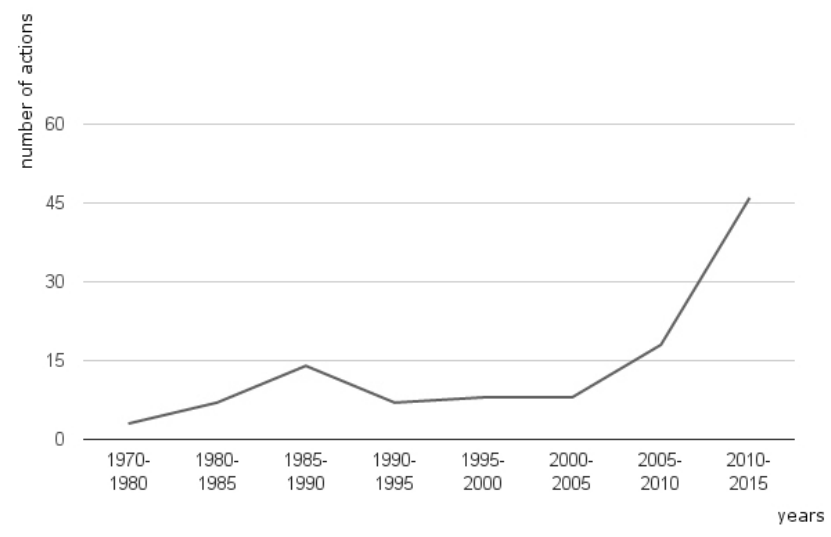

Figure 2. Rammed earth promotion actions in Auvergne-Rhône-Alpes since 1970

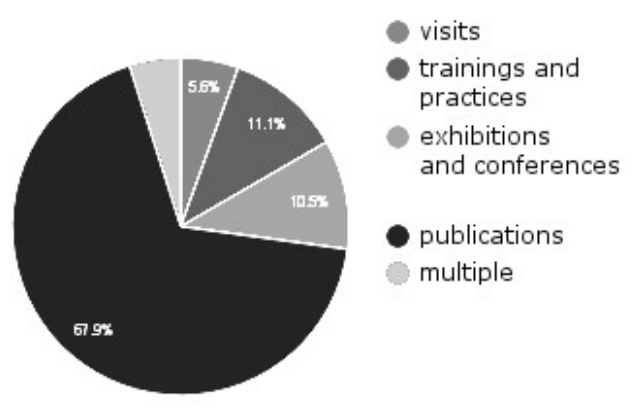

Figure 3. Types of rammed earth promotion actions 
This research encountered many issues related to the time and material constraints. Indeed, time for data gathering was limited to about two weeks. We also met problems accessing all information on the web: old projects having no online documentation, and some projects were less focused on communication. Access to paper archives was limited due to the time constraints. Thus, the information collected could be more consistent. Further research should be committed to standardize this data.

As vocational training is already been included in an underway research (Ortolan et al. 2013), it was decided not to duplicate the work.

\section{BUILDING A COMPREHENSIVE VIEW OF THE NETWORK OF PUBLIC ACTORS INVOLVED IN RAMMED EARTH MANAGEMENT IN FRANCE}

Rehabilitation and retrofitting of old rammed earth constructions relate to many public and private actors through various subjects. Diverse levels of involvement are observed among these actors as well as very different approaches. The aim of this part of the research was to get an overview of the network of actors whom activities affect rammed earth buildings.

\section{Method}

The data collection focused on the public structures related to rehabilitation and retrofitting of historic and vernacular rammed earth constructions. It was made concurrently and linked to the survey on rammed earth promotion actions as the last allowed to identify a number of actors.

It was completed with a study of the local and national public administrations structures. As for the rammed earth promotion actions survey, the limited time couldn't allow for a complete inventory but nonetheless provides a useful overview of the situation.

\section{Diverse links and subdivided authority}

The data collected shows that many public structures are related to rehabilitation and retrofitting of historic and vernacular rammed earth construction. Although they're not necessarily engaged in specific actions about rehabilitation or preservation, their actions may enable or already include it, and call to diverse fields of expertise and policy. These fields are all in relation with rammed earth, however the issues they develop are not always coinciding. For instance it can be difficult to find common grounds between heritage, retrofitting focused on energy savings and town planning policies.

The fields covered by the identified organizations are heritage promotion, research and development, housing, retrofitting, ecological building, training, assistance for building (especially for self-building), territorial development and heritage projects.

This diversity reflects various modus operandi and various kinds of actors: public bodies' officers, private professionals organized in federations or associations to undertake specific projects, professionals and volunteers from nonprofit organizations. Some bodies show a hierarchical organization with territorial agencies.

\section{Developing tools with and for public actors}

Regional and local authorities are a very important piece of the network of actors involved in the rehabilitation and retrofitting of old rammed earth constructions due to their spheres of competence. In contact with the daily needs of their territories, they are responsible for setting up territorial development policies while maintaining infrastructures, cultural wealth and local characters. It is therefore especially important that these local authorities have at their disposal resources and 
methods to undertake their daily activities as well as targeted projects in accordance with the specificities of the historic and vernacular rammed earth constructions.

Yet, the analysis of surveyed projects and initiatives showed a lack of actions towards local and regional authorities and a majority of actions targeted at cultural promotion of rammed earth. As practices and needs dealt with by local authorities seems to be closer to everyday issues and uses, the last part of this research focuses on this scope rather than heritage-based approaches. Based on the analysis presented above, we aimed to co-construct a rammed earth constructions management tool targeted to local and regional authorities.

\section{Towards a better management of rammed earth buildings}

The process engaged to setup this tool brings to the forefront dialogue with the public actors involved in spheres of competences related to rammed earth. Methodological foundations were established from the analysis of the identified projects and initiatives around historic and vernacular rammed earth constructions and from methodological guidelines for projects targeted to public actors (Fauvel et al., 2015). They were discussed and amended during workshops with local actors and during in-depth discussions with some professionals from public bodies of Isère territory (Fig. 4).

These first exchanges brought out the main approaches of rammed earth constructions in the public bodies practices and policies through the concerns raised by the participants. These questions make visible how transversal old rammed earth constructions preservation and retrofitting is. It concerns many actors in the territory and implies decisions at big scales as well as everyday activities. They also highlight a range of issues: temporality and governance, heritage knowledge and training, or consistency of the policies across the decision-making levels.

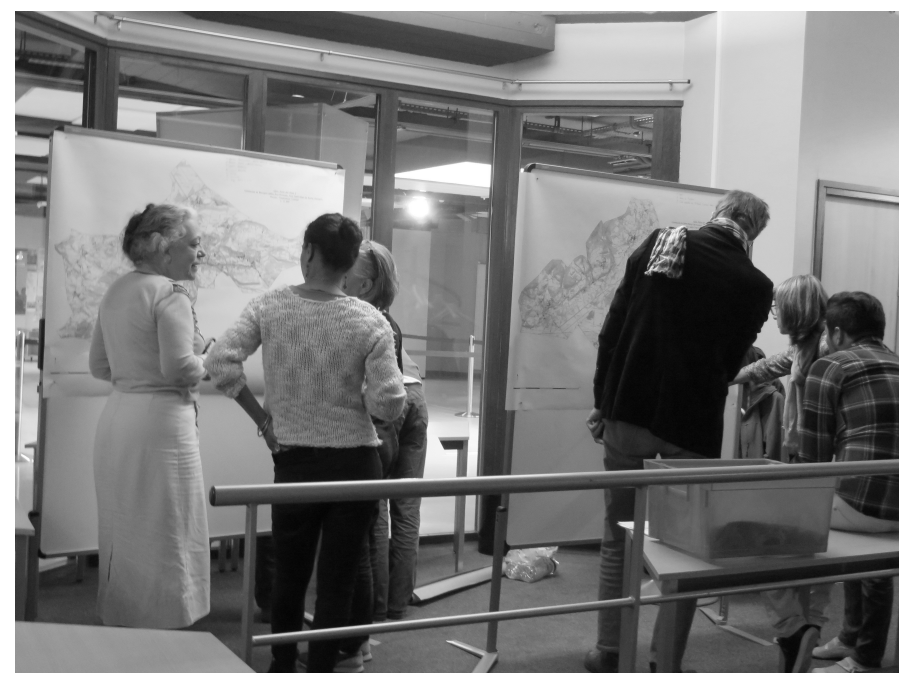

Figure 4. Co-constructing a tool: workshop with local authorities and professionals from public sector

\section{CONCLUSIONS}

This project allowed to improve at the same time the knowledge of rammed earth constructions and the public stakeholder's dynamics around it in Auvergne-Rhône-Alpes region. The co-construction process engaged with local authorities is leading up to a methodological tool for the rammed earth constructions management in this territory.

The project updated the regional mapping of rammed earth constructions and provided interoperable data at municipal level. The current dataset includes buildings protected at a national level as "Monument Historique" and areas of protection. This work is a foundation from which the knowledge of rammed earth distribution in the region territory can be refined. It can also be helpful to incorporate rammed earth in the local and regional authorities GIS. 
On management grounds, the aim in the long run is to co-construct a methodological tool allowing to catch the width of rammed earth range in public policies. Within this project, the process to create this tool was initiated and the tool is in the first steps of being tested while this paper is written. It already proves its ability to open a dialogue on the integration of rammed earth old constructions in local policies.

The collaboration with various public bodies is still underway. The trajectory initiated by the project is to reinforce links between stakeholders and explore tracks to make this dynamics sustainable. The activities considered to extend the project are for instance:

- the setting up of meetings gathering public bodies concerned with rammed earth issues, including collectives and organizations from outside the region who have an experience of working together around earth buildings management;

- the assembly of an application for the inscription of Auvergne-Rhône-Alpes rammed earth on the World Heritage List.

The progress of the research can be followed online: terrespise.hypotheses.org

\section{REFERENCES}

Bertin, D., Clémençon, A.S., 1983. L'architecture en terre, un mode de construction urbain? Le cas de Lyon et sa Banlieue. In Ministère de l'urbanisme et du logement. François Cointeraux 1740-1830. Architecture de terre.

Electricité de France. Pact, 1985. Le bâti ancien des pays de l'Ain, Paris-La Défense.

Fauvel, M.-M., Langlois, C., Fédération nationale des agences d'urbanisme (Eds.), 2015. Le patrimoine territorial en projet. FNAU : Alternatives, Paris.

Guibaud, C., 2005. L'architecture en pisé dans le canton de Boën (Loire). In Situ. Revue des patrimoines. doi:10.4000/insitu. 8307

Joffroy, T., Sapere, D., Baldussi, A., 1991. Patrimoine architectural en pisé et en galets en pays de Valloire-Galaure. Repérage de bâtiments typiques et particuliers. GICAM CRATerre-EAG, Saint Vallier, Grenoble.

Leylavergne, E., Beziane, A. 2012. Les liens spatiaux entre géologie, pédologie, patrimoine en terre crue, professionnels de la terre crue. ENSAG, Grenoble.

Magnaghi, A., 2003. Le projet local. Mardaga, Sprimont.

Micoud, A., 2007. Des patrimoines aux territoires durables. Ethnologie française 34, 13-22.

Mille, E., 2016. Le pisé dans la métropole lyonnaise: si présent, si méconnu: un bâti remarquable à découvrir, valoriser et pérenniser. ENSAG, Grenoble.

Ortolan, J., Chatellier, X., Dugelay, S., Jalabert, B., Mervoyer, A., Micmacher, M., Portela, P., 2013. Etat des lieux des formations faisant référence à des systèmes constructifs utilisant des matériaux biosourcés et/ou des matériaux utilisés dans les SCNI hors bois d'œuvre. Etude réalisée par la Fédération Écoconstruire pour DGALN / PUCA DHUP.

Raulin, H., 1977. Dauphiné. Berger-Levrault, Paris.

Royer, C., 1979. Lyonnais. Berger-Levrault, Paris.

Scarato, P., 1984. Inventaire du patrimoine en pisé du département de la Loire. Clermont-Ferrand: Pisé Terre d'avenir. Studer, D., 2016. Clés de lecture et enjeux de l'architecture de terre en Pays Voironnais. ENSAG, Grenoble. 
${ }^{\mathrm{i}}$ In this paper, we consider historic and vernacular buildings built before 1948 according to INSEE

ii This project benefits of French State Funding, through ANR-10-LABX-78 (Labex AE\&CC) 